\title{
On the extraordinary depression of the barometer on January 13th, 1843
}

\section{Henry Hough Watson Esq.}

To cite this article: Henry Hough Watson Esq. (1843) On the extraordinary depression of the barometer on January 13th, 1843, Philosophical Magazine Series 3, 22:143, 158-159, DOI: $10.1080 / 14786444308636338$

To link to this article: http://dx.doi.org/10.1080/14786444308636338

册 Published online: 01 Jun 2009.

Submit your article to this journal $[\pi$

Џ Article views: 2

Q View related articles $\asymp$ 
have transferred to the November Number of your Journal, consisted in first bringing the observed pressures to what they would be at the neutral point of temperature, applying next the correction for capacity, then bringing the resulting barometric heights to what they would be at $32^{\circ}$, and lastly adding the corrections for capillarity. There is, I need not say, nothing peculiar in this process. Not having by me the portable barometer (one by Newman) which I used in my experiments, I cannot exactly state the neutral points of pressure and temperature, and the corrections for capacity and capillarity peculiar to it, and which are, as usual, engraved upon its mounting. I may mention, however, that the coefficient of mercurial expansion for one degree Fahrenheit which I have employed in the reductions is 0001 ; the number very nearly which results from the well-known experiments of Dulong and Petit. I apprehend that Mr. Moyle has been led into error by supposing me to have used a syphon barometer with moveable scales, an instrument whose indications require to be corrected for temperature alone.

I am, Gentlemen, your obedient Servant,

28 S. Baggott-Street, Jan. 16, 1843.

James Apjohn.

ON THE EXTRAORDINARY DEPRESSION OF THE BAROMETER ON JANUARY 13TH, 1843. BY H. H. WATSON, ESQ.

To the Editors of the Philosophical Magazine and Journal.

Gentlemen,

The very extraordinary depression of the barometer which occurred yesterday, will doubtless have been noted by many of your readers; and probably the subjoined account of the observations made by me, at this town, on the height of the mercurial column, will not be unacceptable for publication in your Journal; as, by comparison with the notes made by distant observers, they may assist in showing how far the depression has been general.

\begin{tabular}{|c|c|c|c|c|c|c|}
\hline \multirow{2}{*}{ 13th Jan. 1843} & \multicolumn{3}{|c|}{$\begin{array}{l}\text { Height of the } \\
\text { Mercurial columin. }\end{array}$} & \multicolumn{3}{|c|}{$\begin{array}{l}\text { Height of the } \\
\text { Mereurial column. }\end{array}$} \\
\hline & 9 А.M. & $27 \cdot 81$ & neh. & Half-past & 3 р.м. & $27 \cdot 81 \mathrm{in.}$ \\
\hline & 10 A.M. & $27 \cdot 77$ & & & 4 P.M. & $27 \cdot 85 \ldots$ \\
\hline oast 1 & 10 A.M. & $27 \cdot 75$ & $\ldots$ & Half-past & 4 P.м. & $27 \cdot 87 \quad \ldots$ \\
\hline & 11 A.M. & $27 \cdot 73$ & $\cdots$ & & 5 P.M. & $27 \cdot 87 \ldots$ \\
\hline Half-past 1 & $11 \mathrm{~A} . \mathrm{M}$ & $27 \cdot 72$ & ... & Half-past & 5 P.м. & $27 \cdot 87 \quad \ldots$ \\
\hline & 12 & $27 \cdot 72$ & $\cdots$ & & 6 р.м. & $27 \cdot 88 \ldots$ \\
\hline Half-past 1 & 12 P.M. ${ }^{\prime}$ & $27 \cdot 72$ & $\cdots$ & & 7 P.M. & $27.94 \quad \ldots$ \\
\hline & $1 \mathrm{r}: \mathrm{M}$ & $27 \cdot 73$ & ... & & 8 Р.м. & $27 \cdot 97 \ldots$ \\
\hline Half-past & 1 P.M. & $27 \cdot 74$ & $\cdots$ & & 9 р.м. & $28^{\circ} 01 \ldots$ \\
\hline & 2 P.M. & $27 \cdot 76$ & $\cdots$ & & 10 P.M. & $28.03 \ldots$ \\
\hline Half-past & 2 P.M. & $27 \cdot 77$ & $\cdots$ & & 11 P.M. & $28 \cdot 04 \ldots$ \\
\hline & 3 P.M. & $27 \cdot 79$ & $\cdots$ & & & \\
\hline
\end{tabular}

The greatest depression was from half-past 11 A.M. to half-past 12 ; the height of the mercury then being $27 \cdot 72$ inches. The mean annual height of the barometer at this town, as obtained from my observations made morning, noon, and night during twelve years, com- 
mencing January 1831 , is 29.564 inches. With the exception of yesterday, the lowest height of the barometer during the time which has elapsed since I commenced keeping a register, was 28.04 inches : it occurred at 6 P.M. on the 13 th of November 1840 .

The weather in the early part of yesterday, and till evening, was similar to what it had been for several days previously; a little snow, hail and rain falling at intervals. The wind was rather south of west, but not strong, till about 7 P.M., when it began to blow strongly, and during the night and till daybreak this morning was very boisterous; it then began to abate, and by 9 A.M. was not unusually strong.

'The temperature here yesterday ranged from $35^{\circ}$ to $36^{\circ}$; today it has ranged from $34^{\circ}$ to $30^{\circ}$ : at half-past 10 on the night of the 12 th instant it was $27^{\circ}$, and the height of the barometer at that time was $28 \cdot 70$ inches. Today the height of the barometer has been at 8 A.M. 28.58 inches; at half-past 12 P.M. 28.54 inches, and at half-past 10 at night 28.57 inches; the weather simtlar to that of the several previous days.

It will be found by reference to the observations of Mr. Luke Howard, page 69, vol. iii. of his work, entitled "The Climate of London," that a depression of the barometer, similar to that of yesterday, occurred in December 1821.

I remain, Gentlemen, yours most respectfully,

Bolton-le-Moors, Jan, 14, 1843. Henry Hough Watson.

\section{METEOROLOGICAL OBgERVATIONS FOR DECEMBER 1842.}

Chiswick.-Dec. 1. Slight rain : overcast. 2. Densely clouded : clear and fine. 3. Foggy. 4. Foggy : overcast. 5. Light haze: very fine : foggy. 6-9. Foggy. 10, Overcast. 11. Foggy : clear and fine. 12. Rain: overcast and mild. 13. Very fine : overcast. 14,15. Exceedingly fine. 16. Very fine : densely overcast. 17. Very fine. 18, 19. Foggy : clear and fine, 20, 21. Hazy. 22. Very fine. 23. Rain. 24, Very fine. 25. Clear : overcast and fine : stormy at night. 26. Cloudy and windy. 27. Rain : cloudy and damp: frosty. 28. Frosty : clear and fine. 29. Densely clouded. 30. Cloudy and very mild. 31. Very fine.-Mean temperature of the month $4^{\circ} \cdot 12$ above the average.

Boston. -Dec. 1-3. Cloudy. 4. Foggy. 5. Cloudy. 6. Foggy. 7. Cloudy. 8, 9. Foggy. 10. Foggy: rain early A.M. 11. Cloudy. 12. Rain : rain early A.m. 13. Cloudy. 14, 15. Fine. 16. Cloudy : rain P.M. 17-19. Fine. 20. Cloudy, 21, 22. Fine. 23. Cloudy. 24. Fine. 25. Fine: rain P.M. 26. Windy : rain P.M. 27. Cloudy : rain early A.M. 28. Fine. 29. Windy. 30. Fine. 31. Windy : stormy r.M.

Sandwick Manse, Orkney.-Dec. 1. Rain: cloudy. 2. Showers : cloudy. 3. Clear: showers. 4. Cloudy: drizzle. 5,6, Bright: cloudy, 7. Cloudy. 8. Drizzle. 9. Fog. 10. Fog : cloudy. 11. Cloudy. 12. Rain : cloudy. 13, 14. Cloudy. 15. Bright : cloudy. 16. Bright. 17, 18. Showers. 19. Showers : clear. 20. Showers : cloudy. 21. Cloudy : drizzle. 22. Showers. 23. Showers: snow. 24. Showers. 25. Rain. 26, 27. Hail-showers, 28, 29. Cloudy, 30. Rain : drizzle. 31. Showers : frost.

Applegarth Manse, Dumfries-shire-Dec. 1, 2. Rain and wind. 5. Fine and fair. 4. Rain A.M.: cleared. 5,6. Rain P.M. 7. Fair and fine. 8. Fair A.M.: drizaly P.M. 9. Fair but cloudy. 10. Drizzly. 11. Fair : overcast p.M. 12. Wet all day. 13. Storm : wind : rain : flood. 14. Rain P.M. 15, 16. Storm : wind : rain P.M. 17. Fair. 18-23. Showers P.M. 24. Hoar-frost A.M. 25. Very wet all day, 26. Very wet A.M. 27. Slight shower: frost P.M. 28. Frost A.м.: rain P.M. 29. Rain, but mild. 30. Rain and high wind. 31. Rain: cleared P.M.

The high temperature of December is remarkable, being nearly $10^{\circ}$ higher than the mean of the last twenty years, and $7^{\circ}$ higher than Dec. 1841 . 